\title{
Self Efficacy and Emotional Quotient in Mediating Active Learning Effect on Students' Learning Outcome
}

\section{K. Kustyarini}

Dr., Department of Language, Wisnuwardhana University Malang-Indonesia, kustyarinireinanda@yahoo.com

The purpose of this study is to analyze the self-efficacy and emotional intelligence in mediating the effect of implementing active learning methods on student learning outcomes. The population of this study is the population in this study were Indonesian language and literature education students in East Java who were taking Indonesian Language courses with a sample size of 160 students. Data analysis in this research uses Structural Equation Modeling. The results showed that the active learning method had a significant influence on the learning outcomes of students studying Indonesian. The role of students in active learning such as actively expressing opinions related to the material delivered by lecturers, participating groups in working / discussing the tasks given, interacting well during the lessons, being able to explain the subject matter well and having feedback on the learning process has an impact on increased self-efficacy such as encouraging students to have the ability to self-evaluate the ability or competence to carry out a task, achieve goals or overcome obstacles. The existence of active learning helps students improve emotional intelligence such as trying to hold excessive emotional emotions, trying not to do things from the encouragement of negative traits and think about what they want before acting, and have the spirit to become a better person, happy to face challenges to solve problems and not giving up when doing difficult tasks. When self-efficacy and emotional intelligence are achieved, it will have an impact on improving student learning outcomes through Indonesian Language courses.

Keywords: active learning method, self-efficacy, emotional quotient, learning outcomes, learning

\section{INTRODUCTION}

Language education is very important in community life because the function of language is essentially a tool of communication. In addition, Indonesian language learning has an important role to improve language skills. Indonesian is a compulsory subject in universities, both public and private (Hilaliyah, 2015). There are several

Citation: Kustyarini, K. (2020). Self Efficacy and Emotional Quotient in Mediating Active Learning Effect on Students' Learning Outcome. International Journal of Instruction, 13(2), 663-676. https://doi.org/10.29333/iji.2020.13245a 
reasons why the government determined this. A common reason is it serves as a guide for native speakers of languages namely students are able to use good and correct Indonesian language and it must be continuously carried out. The specific reason underlying this determination is because students are considered as prospective graduates so they must be trained in terms of their ability to use official and straightforward writing. Students are required to have the ability to compile papers, reading reports, and make research reports that are not only weighty, but they should also have clear reasoning and coherent narrative. This ability is specifically noted in the lecturing preparation of Indonesian Language materials in universities (Arifin, 2006).

Indonesian Language course is one of the subjects that is frequently underestimated by students because they learn this as their everyday language. They do not realize that actually learning the Indonesian language is not only enough in terms of its oral practice, but it should be accompanied by the ability to write proper Indonesian language both in formal and informal situations. The success of the Indonesian language learning process can be measured by the success of students who take part in the activity. The success can be seen from the level of understanding and mastery of the material, so that the higher the understanding and mastery of the material, the higher the success rate of learning.

Basically, student learning achievements can be influenced by several factors, including student perceptions of the learning methods used by lecturers during the teachinglearning process. Student perceptions of active learning influence the success of learning. Perception of active learning is the assessment, understanding, and feeling of students towards the concept of learning showing by a condition of students who always have meaningful learning experiences as they always think about what they can do during learning. In this condition, students must function their brain, study ideas, find solutions to solve problems and apply what they learn. Therefore, students' activeness in learning is more dominant (Silberman, 2011) and active learning has been proven to be more effective for learning (Freeman et al. 2014).

Zimmerman \& Risemberg (1997); Sungur \& Tekkaya (2006) show that beliefs and awareness to allow students to become free learners are closely related to improving academic quality. Dolan, (2015) revealed individual factors and classrooms contributed to student involvement, performance, and perseverance through active learning. Mueller, et al. (2018) students who are active in-class learning have more positive perceptions of learning experiences compared to students who are passive learning in class. Fayombo (2013), Jeong et al. (2019) and Aji and Khan (2019) show that active learning has a positive impact on student learning outcomes.

Learning success is also influenced by self-efficacy (Self-Efficacy), a student with selfefficacy can improve learning outcomes. This is because self-efficacy is an individual evaluation of the ability or competence to perform a task, achieve goals or overcome obstacles. Student self-efficacy arises when students get information from four main sources, such as experiences of self-mastery, experience in observing others, social persuasions students receive from others, and emotional and psychological states (Betoret, et al. 2017). Chang and Chien (2015) revealed that self-efficacy refers to 
individual abilities that can be used to complete studies, control behavioral abilities, and assess academic achievement. Putwain et al. (2013) concluded that self-efficacy can predict student academic performance and can predict emotions related to learning through academic performance. Noreen, et al (2018) concluded that self-efficacy has an influence on student learning outcomes. Thus, individuals with low self-efficacy will easily give up when facing academic difficulties and individuals with high self-efficacy will persevere in the face of adversity, and try to overcome them thoroughly.

Increased student self-efficacy due to the role of lecturers in conducting the learning process through active learning methods. The learning process with active learning methods encourages students to have the ability to self-evaluate the ability or competence to carry out a task, achieve goals or overcome obstacles. Fook et al. (2015) and Jeong, et al. (2019) concluded that active learning methods contribute to student self-efficacy.

Learning outcomes are not only determined by the value in the form of numbers but more importantly learning outcomes as a learning process that is deliberately carried out with the aim of forming self-knowledge and skills for learning inside and outside the classroom. For effective learning, work can be achieved optimally when paying attention to aspects of emotional intelligence that is a feeling that perceives into the student's personality. Brouzos, et al (2014), Rayung and Ambotang (2018) concluded that emotional intelligence has a positive relationship with student academic achievement.

The learning process not only makes students have the knowledge but is also able to utilize that knowledge in life and even produce their own knowledge. So that learning can optimize student competence, it is necessary for learning to really be able to increase the variety of intelligence they have, including student emotional intelligence. Learning that is able to optimize the emotional intelligence of students in active learning. Mursid and Kesuma (2012) that there is an interaction between the use of learning strategies with emotional intelligence in influencing learning outcomes

This research tries to conduct a comprehensive study of self-efficacy and emotional quotient in mediating the influence of active learning method implementation toward Indonesian language and literature education students learning outcomes in east java.

\section{LITERATURE REVIEW}

\section{Active Learning Method}

Active learning is an alternative that allows for contextualization to create active student participation in the learning process (Munthe, 2015). Active learning is describing learning in which students actively build their own knowledge. The way to implement active learning is that students work with other students while in class and more often assess learning between students in the class (Eddy et al. 2015b). Dolan, (2015) revealed individual factors and classrooms contributed to student involvement, performance, and perseverance through active learning. Mueller, et al. (2018) students who are active in-class learning have more positive perceptions of learning experiences compared to students who are passive learning in class. Fayombo (2013), Jeong et al. 
(2019) and Aji and Khan (2019) show that active learning has a positive impact on student learning outcomes. Fook et al. and Jeong, et al. (2019) concluded that active learning methods contribute to student self-efficacy.

\section{Self Efficacy}

Self-efficacy is the ability of individuals in self-regulation (Baron and Byrne, 2005). Ormrod (2009) self-efficacy is an individual's assessment of the ability to do a task, achieve a goal, and produce something. Bandura, (1997) self-efficacy refers to beliefs about the ability to organize and implement actions to achieve results. Hjelle and Zigler (1992) individuals believe that he can execute behavior to produce specified responsibilities. According to Pajares \& Miller (1994) self-efficacy also affects a number of stresses and experiences of individual anxiety such as when they are busy in an activity.

The construct of self-efficacy is divided into two dimensions namely (1) self-belief and (2) outcome expectancy. This self-confidence means a person's belief in being able or able to master the behaviors needed to achieve achievement, Bandura (1997). Pajares (1996: 20-35) suggested that self-efficacy as an individual belief can influence learning actions and willingness to complete tasks related to learning goals.

\section{Emotional Quotient}

Emotional quotient is the power of the subconscious thinking that functions as a controlling or driving force that is driven logically. Salovey and Mayer (1990) defined emotional quotient or what is often called emotional quotient (EQ) as: "a subset of social quotient that involves the ability to monitor social feelings that involve abilities in others, by sort out everything and use this information to guide the mind and actions (Shapiro, 1998). Jensen et al. (2008) stated that emotional quotient (EQ) can be defined as the ability to understand and recognize the emotional state of oneself and others. Goleman (1996) emotional quotient is the ability to motivate oneself and survive facing frustration, controlling impulses, regulating moods and keeping the stress burden from paralyzing the ability to think, empathize and pray. While Cooper \& Sawaf (1998) stated that emotional quotient is the ability to feel, understand, and effectively apply emotional power and sensitivity as a source of energy, information, and human influence.

\section{Learning outcomes}

Learning outcomes are the efficiency and results achieved by students through the learning process expressed by values based on learning tests (Briggs, 1979). According to Gagne \& Driscoll (1988), learning outcomes are abilities possessed by students as a result of the learning process. According to Gagne and Briggs (1979), there are five categories of learning outcomes, namely: (1) intellectual skills, (2) cognitive strategies, (3) verbal information, (4) motor skills, and (5) attitudes. Reigeluth (1983) argues that learning outcomes as influences that provide a measure of the value of alternative methods under different conditions because there are tangible and desirable results. Riegeluth (1983) says that specific learning outcomes are performance shown as 
abilities that have been obtained. Learning outcomes are always expressed in the form of goals (specifically) and behavior (performance). Bloom (1982) suggests three main factors that influence learning outcomes, namely cognitive, affective, and psychomotor.

\section{HYPOTHESIS DEVELOPMENT}

Zimmerman \& Risemberg (1997); Sungur \& Tekkaya (2006) beliefs and awareness to allow students to become free learners are closely related to improving academic quality. Akinoglu and Tandogan (2007); that the active learning model contributes to student academic achievement and student conceptual development. Dolan, (2015) revealed individual factors and classrooms contributed to student involvement, performance, and perseverance through active learning. Mueller, et al. (2018) students who are active in-class learning have more positive perceptions of learning experiences compared to students who are passive learning in class. Fayombo (2013), Jeong et al. (2019) and Aji and Khan (2019) show that active learning has a positive impact on student learning outcomes.

\section{H1: Active learning method influences student learning outcomes}

Increased student self-efficacy due to the role of lecturers in conducting the learning process through active learning methods. The learning process with active learning methods encourages students to have the ability to self-evaluate the ability or competence to carry out a task, achieve goals or overcome obstacles. Fook et al. and Jeong, et al. (2019) concluded that active learning methods contribute to student selfefficacy. Chang and Chien (2015) revealed that self-efficacy refers to individual abilities that can be used to complete studies, control behavioral abilities, and assess academic achievement. Wilke (2003) showed that there were differences in self-efficacy in the treatment group and the control group after receiving active learning. Putwain et al. (2013) concluded that self-efficacy can predict student academic performance and can predict emotions related to learning through academic performance. Wang, \& Chen (2012) showed that self-efficacy has a strong relationship with learning outcomes and student learning satisfaction. Papasraton \& Wangpipatwong (2006) concluded that selfefficacy is a determining factor in success (outcomes). Gaskill and Murphy (2004) showed that efficacy belief significantly influences academic achievement. Noreen, et al (2018) concluded that self-efficacy has an influence on student learning outcomes. Thus, individuals with low self-efficacy will easily give up when facing academic difficulties and individuals with high self-efficacy will survive in the face of adversity, and try to overcome them thoroughly

H2 Self-efficacy mediates the effect of active learning method on student learning outcomes

Baron (1997); Benson (2009) described social-emotional quotient as an aggregate of emotional and social competencies that are interrelated, the skills to understand and express themselves, understand others. the description above shows that emotional quotient is a side of interpersonal quotient and intrapersonal quotient possessed by humans and is considered to play a role in determining the level of success of his life. Benson (2009) stated that emotional quotient has been identified as a set of 
competencies needed to achieve success. Learning that is able to optimize the emotional intelligence of students in active learning. Mursid and Kesuma (2012) that there is an interaction between the use of learning strategies with emotional intelligence in influencing learning outcomes. Whereas Brouzos, et al (2014), Rayung and Ambotang (2018) concluded that emotional intelligence has a positive relationship with students' academic achievement

H3 Emotional quotient mediates the effect of active learning method on student learning outcomes.

\section{METHOD}

This research is an explanatory study, the pattern of influence that will be studied in this study is the influence of perceptions on the application of active learning methods to self-efficacy, emotional quotient, and student learning outcomes. Judging from the method and level of exploration, this research is survey research which is a quantitative study using the same structured or systematic questions to the respondents, then all the answers obtained are recorded, processed, and analyzed.

The population of this research is Indonesian language and literacy education students in East Java who are taking an Indonesian language course. The population in this research is an infinite population, which is a very large population size so that the population cannot be known for certain. In these conditions, the sample size is determined by referring to the opinion of Ferdinand (2006) stating that the sample size is determined by multiplying the number of indicators by $5-10$. Based on these provisions, the sample size used is $16 \times 10=160$ respondents.

The operational definition of the variables reviewed through this research includes (1) active learning methods. (2) self-efficacy, (3) emotional quotient, and (4) learning outcome. This is explained by the operational definition of each variable as follows:

Table 1

Operational Variable

\begin{tabular}{|c|c|c|}
\hline Variable & Indicator & Source \\
\hline $\begin{array}{l}\text { Active } \\
\text { learning } \\
\text { method }\end{array}$ & $\begin{array}{l}\text { Actively express opinions related to the material presented by the lecturer } \\
\text { Participate in groups in working on / discussing the tasks given } \\
\text { Interact well during the lesson } \\
\text { Can explain subject matter well } \\
\text { There is feedback in the learning process }\end{array}$ & $\begin{array}{l}\text { Bonwell, (1995), } \\
\text { Silberman (1996), }\end{array}$ \\
\hline $\begin{array}{l}\text { Self- } \\
\text { efficacy }\end{array}$ & $\begin{array}{l}\text { Individual confidence in the degree of difficulty of the task or work that } \\
\text { can be carried out } \\
\text { Individual beliefs about his own competencies } \\
\text { Individual confidence in generalizing previous experiences }\end{array}$ & $\begin{array}{l}\text { Bandura, (1997), } \\
\text { Pajares (1997), } \\
\text { Bar-On (1997) }\end{array}$ \\
\hline $\begin{array}{l}\text { Emotional } \\
\text { quotient }\end{array}$ & $\begin{array}{l}\text { The ability to recognize emotions } \\
\text { Ability to manage emotions } \\
\text { Self-motivating ability } \\
\text { The ability to recognize the emotions of others } \\
\text { The ability to build relationships with other people }\end{array}$ & Goleman, (2002) \\
\hline $\begin{array}{l}\text { Learning } \\
\text { outcome }\end{array}$ & $\begin{array}{l}\text { Cognitive } \\
\text { Affective } \\
\text { Psychomotor }\end{array}$ & Bloom, (1956) \\
\hline
\end{tabular}


In connection with the formulation of the problem, objectives and research hypotheses, the data analysis used in the research is Structural Equation Modeling (SEM). Hypothesis testing uses the CR (critical ratio) coefficient which is analogous to the t-test which is a prob value. (p) and If $\mathrm{p}>0.05$ then $\mathrm{H} 0$ is accepted, if $\mathrm{p} \leq 0.05$ then $\mathrm{H} 0$ is rejected. Whereas to investigate the influence it is indirectly done by comparing the total influence with direct influence. If the total influence is greater than the direct effect, it can be said that self-efficacy and emotional quotient mediate the effect of active learning methods toward student learning outcomes.

\section{FINDINGS}

Testing the data quality is a stage that must be passed by the research model before going through the impact test or correlation test. Generally, data validity illustrate the suitably of each indicator against the variable. The validity of SEM is identified by the "Estimate" value. Ghozali (2013) explains that an indicator of a variable is valid if the "Estimate" value $>0.05$. Based on table 2, shows that the value "Estimate" value> 0.05, so that the indicators used have a high level of validity

Table 2

Validity Test

\begin{tabular}{|c|c|c|c|}
\hline Indicator & & Variable & Estimate value \\
\hline $\mathrm{x} 1.1$ & $<--$ & Active Learning_Methods & 0,738 \\
\hline $\mathrm{x} 1.2$ & $<--$ & Active Learning_Methods & 0,785 \\
\hline $\mathrm{x} 1.3$ & $<--$ & Active Learning_Methods & 0,794 \\
\hline $\mathrm{x} 1.4$ & $<--$ & Active Learning_Methods & 0,776 \\
\hline $\mathrm{x} 1.5$ & $<---$ & Active Learning_Methods & 0,638 \\
\hline $\mathrm{y} 1.1$ & $<--$ & Self-efficacy & 0,774 \\
\hline $\mathrm{y} 1.2$ & $<---$ & Self-efficacy & 0,749 \\
\hline y1.3 & $<--$ & Self-efficacy & 0,805 \\
\hline y2.1 & $<---$ & Emotional_Intelligence & 0,788 \\
\hline y2.2 & $<---$ & Emotional_Intelligence & 0,656 \\
\hline y2.3 & $<---$ & Emotional_Intelligence & 0,765 \\
\hline y2.4 & $<---$ & Emotional_Intelligence & 0,770 \\
\hline y2.5 & $<---$ & Emotional_Intelligence & 0,742 \\
\hline $\mathrm{y} 3.1$ & $<--$ & Achievement_Learn & 0,776 \\
\hline $\mathrm{y} 3.2$ & $<--$ & Achievement_Learn & 0,747 \\
\hline y3.3 & $<---$ & Achievement_Learn & 0,795 \\
\hline
\end{tabular}

\section{The Analysis Result of Goodness of Fit SEM}

The results of testing the overall goodness of fit model, according to the results of SEM analysis is to find out whether the hypothetical model is supported by empirical data. The explanation is given in Figure 1. 


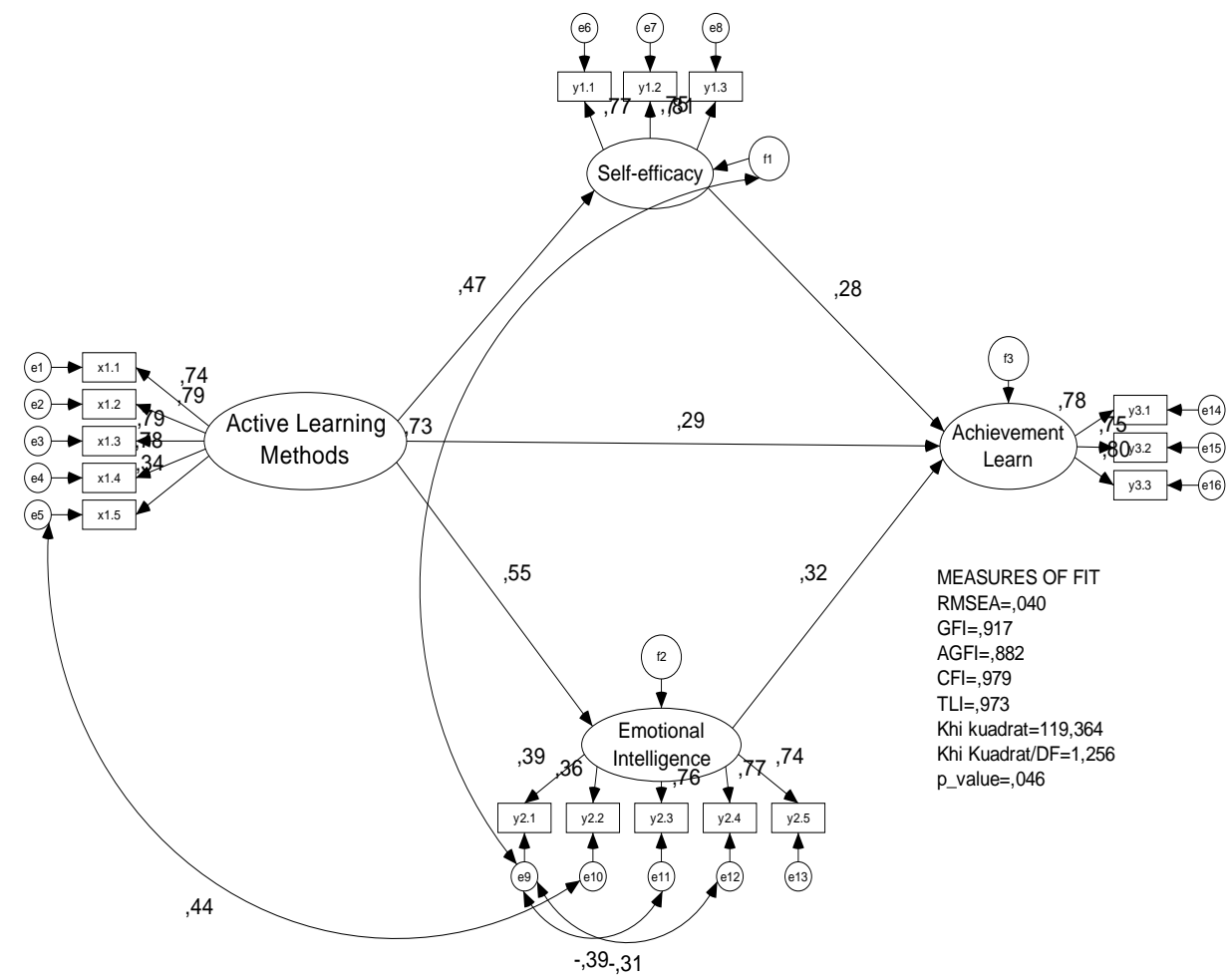

Figure 1

Path Chart Results of SEM Analysis

The results of testing the Overall Goodness of Fit is based on Figure 1. It can be seen that all criteria show a good model so that interpretation can be made for further discussion.

\section{Hypothesis Testing Results}

The results of hypothesis testing are presented in Table 3 below:

Table 3

Results of Regression Weight Analysis

\begin{tabular}{llllll}
\hline Variable & & & Koefisien Jalur & C.R. & P \\
\hline Active Learning Method & $-->$ & Self efficacy & 0,467 & 3,595 & $0.000^{*}$ \\
\hline Active Learning Method & $-->$ & Emotional quotient & 0,551 & 3,709 & $0.000^{*}$ \\
\hline Active Learning Method & $-->$ & Learning outcomes & 0,286 & 2,326 & $0.020^{*}$ \\
\hline Self efficacy & $-->$ & Learning outcomes & 0,279 & 3,009 & $0.003^{*}$ \\
\hline Emotional quotient & $-->$ & Learning outcomes & 0,322 & 3,317 & $0.000^{*}$ \\
\hline
\end{tabular}

* significance on $5 \%$ level 
The testing of indirect effects is used from several results of direct influence testing. Complete results of the direct effect testing are presented in Table 3 below:

Table 4

The Result of Hypothesis Testing on Indirect Effect

\begin{tabular}{llllll}
\hline $\begin{array}{l}\text { The effect } \\
\text { among } \\
\text { variables }\end{array}$ & $\begin{array}{l}\text { Direct } \\
\text { effect }\end{array}$ & $\begin{array}{l}\text { Indirect effect } \\
\text { Through } \mathrm{Y}_{1}\end{array}$ & Through $\mathrm{Y}_{2}$ & $\begin{array}{l}\text { Through } \\
\mathrm{Y}_{1}\end{array}$ & $\begin{array}{l}\text { Through } \\
\mathrm{Y}_{2}\end{array}$ \\
\hline $\mathrm{X}_{1}$ toward $\mathrm{Y}_{1}$ & 0,467 & - & - & 0,467 & \\
\hline $\mathrm{X}_{1}$ toward $\mathrm{Y}_{2}$ & 0,551 & - & - & 0,551 & \\
\hline $\mathrm{X}_{1}$ toward $\mathrm{Y}_{3}$ & 0,286 & $\begin{array}{l}0.467 \times 0.279 \\
0.130\end{array}$ & $\begin{array}{l}0.551 \times 0.322 \\
0.177\end{array}$ & 0.416 & \multirow{2}{*}{0.463} \\
\hline $\mathrm{Y}_{1}$ toward $\mathrm{Y}_{3}$ & 0,279 & - & - & 0,279 & \\
\hline $\mathrm{Y}_{2}$ toward $\mathrm{Y}_{3}$ & 0,322 & - & - & 0,322 & \\
\hline
\end{tabular}

Information:

$\mathrm{X} 1$ : Active learning method

Y1: Self-efficacy

Y2: Emotional quotient

Y3: Learning outcomes

Based on Table 4, it can be explained that the indirect effect of active learning methods on student learning outcomes through self-efficacy has a total coefficient value of 0.416 and it is greater than the direct effect of active learning methods on student learning outcomes of 0.286 . These results indicate that self-efficacy can mediate the effect of active learning methods on student learning outcomes.

The indirect effect of active learning methods on student learning outcomes through emotional quotient has a total coefficient of 0.463 and it is greater than the direct effect of active learning methods on student learning outcomes of 0.286 . These results indicate that emotional quotient can mediate the effect of active learning methods on student learning outcomes.

\section{DISCUSSION}

There is an influence of the active learning method on student learning outcomes taking the Indonesian language. It can be explained that the success of learning is basically a positive change during and after the learning process is carried out. This success can be seen from the involvement of students actively in the learning process and the positive changes that arise as a result of the learning process. Student involvement is not only seen in terms of physical, but more important is from the intellectual and emotional aspects during the learning activities, and students experience changes consciously or unconsciously after experiencing the learning process.

The role of students in active learning can be seen from their activities like actively expressing opinions related to the material delivered by lecturers; participating in group work/ discussing the tasks given; being able to interact well during the lesson; being able to explain the subject matter well and giving feedback on the learning process has an impact on improving student learning outcomes. This result is in line with the opinion 
of Zimmerman and Risemberg (1997); Sungur \& Tekkaya (2006) stating that beliefs and awareness to allow students to become free learners are closely related to improving academic quality. This view can provide an increase in the teaching and learning process in the classroom and its contextual factors that will conclusively influence student learning and learning motivation. The results of this research corroborate research conducted by Akinoglu and Tandogan (2007) who concluded that a positive learning model affects student academic achievement and student conceptual development. Dolan, (2015) revealed individual factors and classrooms contributed to student involvement, performance, and perseverance through active learning. Mueller, et al. (2018) students who are active in-class learning have more positive perceptions of learning experiences compared to students who are passive learning in class. Fayombo (2013), Jeong et al. (2019) and Aji and Khan (2019) show that active learning has a positive impact on student learning outcomes.

Self-efficacy mediates the effect of active learning methods on student learning outcomes. This condition shows that self-efficacy greatly determines how much confidence in the ability of each individual to carry out the learning process to achieve optimal learning outcomes. Individuals who have high self-efficacy will well arrange themselves to learn. There is a belief in him that individuals will be able to complete any task as difficult as learning, confidence has the ability to complete various kinds of tasks and hard work to complete all tasks. This will be able to encourage individuals to be able to plan their learning activities, trying to monitor them and manipulate the environment in such a way as to support their learning activities. Thus, it can be seen that if the individual's self-efficacy is low so it can cause obstacles in the learning process even though the individual has great potential.

In this concept, increasing student self-efficacy through active learning methods is considered to play a big role in the learning process. By implementing active learning, students really play a role and actively participate in learning activities so that teaching goals can be achieved better. In this process, students experience "intellectual-emotional involvement" in addition to their physical involvement. The existence of active learning will shape students to have more ability to find the best alternative in solving every problem related to the lesson, being able to organize themselves to meet the demands as students and dare to face difficulties fairly. In addition, with active learning, students have the courage to be able to speak in public without being afraid of something and have confidence in carrying out their duties and always carry out self-evaluations to be better. In the end, when students have high self-efficacy, they will experience an increase in terms of their learning outcomes

Fook et al. and Jeong, et al. (2019) concluded that active learning methods contribute to student self-efficacy. Chang and Chien (2015) revealed that self-efficacy refers to individual abilities that can be used to complete studies, control behavioral abilities, and assess academic achievement. Wilke (2003) showed that there were differences in selfefficacy in the treatment group and the control group after receiving active learning. Putwain et al. (2013) concluded that self-efficacy can predict student academic performance and can predict emotions related to learning through academic 
performance. ai, Hu, Wang, \& Chen (2012) showed that self-efficacy has a strong relationship with learning outcomes and student learning satisfaction. Papasraton \& Wangpipatwong (2006) concluded that self-efficacy is a determining factor in success (outcomes). Gaskill and Murphy (2004) showed that efficacy belief significantly influences academic achievement. Noreen, et al (2018) concluded that self-efficacy has an influence on student learning outcomes. Thus, individuals with low self-efficacy will easily give up when facing academic difficulties and individuals with high self-efficacy will survive in the face of adversity, and try to overcome them thoroughly

The emotional quotient mediates the effect of active learning methods on student learning outcomes. This condition shows that the learning process not only makes students have the knowledge, but they are also able to utilize that knowledge in life and even produce their own knowledge. In order to optimize student competencies, it is necessary that learning can really improve the variety of quotient it has, including student emotional quotient. Learning that is able to optimize students' emotional quotient is called active learning.

The implementation of active learning in optimizing students' emotional quotient can be done by the lecturers by using the following ways. One of the ways is by starting the lesson patiently which is then improved gradually in its pace to enhance students' enthusiasm and promote a good classroom atmosphere as desired by students and accompany the learning process by creating a good sense of humor that can reduce classroom tension. Under these conditions, students have the ability to use emotions effectively in managing themselves and influence relationships with others positively such as trying to hold back excessive self-emotion, trying not to do things from a negative impulse and thinking about what is desired before acting. In addition, students have a passion for becoming a better person, happy to face challenges to solve problems and not give up when doing difficult tasks. Students who have high emotional quotient will usually try to resist their excessive self-emotion, try not to do things from a negative impulse, and think about what is desired before doing an action, and have the spirit to be a better person, happy to face challenges to solve problems and not easily give up when doing difficult tasks as they believe difficult tasks will improve their learning outcomes.

Baron (1997); Benson (2009) described social-emotional quotient as an aggregate of emotional and social competencies that are interrelated, the skills to understand and express themselves, understand others. the description above shows that emotional quotient is a side of interpersonal quotient and intrapersonal quotient possessed by humans and is considered to play a role in determining the level of success of his life. Benson (2009) stated that emotional quotient has been identified as a set of competencies needed to achieve success. Learning that is able to optimize the emotional intelligence of students in active learning. Mursid and Kesuma (2012) that there is an interaction between the use of learning strategies with emotional intelligence in influencing learning outcomes. Whereas Brouzos, et al (2014), Rayung and Ambotang (2018) concluded that emotional intelligence has a positive relationship with students' academic achievement 


\section{CONCLUSION}

The active learning method contributes to the learning outcomes of students taking the Indonesian language and literature course. It can be explained that the success of learning is basically seen from a positive change during and after the learning process is carried out. Students' involvement is not only seen in terms of physical, but more important is from the intellectual and emotional aspects during the learning activities, and students experience changes consciously or unconsciously after experiencing the learning process.

Further studies are needed regarding student perceptions about the implementation of active learning methods, self-efficacy, and emotional quotient. This needs to be done considering each student has different personal characteristics, both the competencies they have, unequal motivation, varied learning styles, unequal learning environments, different emotional quotient, different learning resources and so on. For this reason, further studies and research are needed to determine the success of learning which includes student's affective, cognitive, and psychomotor domains.

\section{ACKNOWLEDGMENTS}

Thank you to editors and reviewers of International Journal Of Instruction and Wisnuwardhana University Malang Indonesia.

\section{REFERENCES}

Arifin, E., Z., \& Tasai, S. (2006). Cermat berbahasa Indonesia. Jakarta: Akademika Pressindo

Bandura, A. (1997). Social foundation of thought and action: A social cognitive theory. New York: Prentice Hall.

Baron, R. (1997). The emotional quotient inventory (EQ-i): Technical manual. Toronto, Canada: Multi-Health Systems.

Benson, G., Ploeg, J., \& Brown. B. (2009). A cross-sectional study of emotional intelligence in baccalaureate nursing student. Journal Nurse, Education Today, 30(1), 49-55. doi: 10.1016/j.nedt.2009.06.006.

Betoret-Doménech, F., Abellan-Rosello, L., \& Artiga-Gomez, A. (2017). Self-efficacy, satisfaction, and academic achievement: The mediator role of students' expectancyvalue beliefs. Front. Psychol, 8, 1193. doi: 10.3389/fpsyg.2017.01193.

Bloom, B. S. (1956). Taxonomy of educational objective: The classification of educational goals, handbook cognitive domain. New York: Longmans, Green and Co.

Brouzos, A., Misailidi, P., \& Hadjimattheou, A. (2014). Associations between emotional intelligence, socio- emotional adjustment, and academic achievement in childhood: The influence of age. Canadian Journal of School Psychology, 29(2) 83-99. doi: 10.1177/0829573514521976. 
Chadia, A. A., \& Khan, M., J. (2019). The impact of active learning on students' academic performance. Open Journal of Social Science, 7, 204-211. https://doi.org/10.4236/jss.2019.73017.

Chang, F. D., \& Chien, C. W. (2015). Determining the relationship between academic self efficacy and student engagement by meta analysis. 2 nd International Conference on Education Reform and Modern Management, Hong Kong. https://doi.org/10.2991/ermm-15.2015.37.

Dolan, E. L. (2015). Biology education research 2.0. CBE Life Sciences Education, 14(4), ed1. doi:10.1187/cbe.15-11-0229.

Fayombo, G. A. (2013). Active learning strategies and academic achievement among some psychology undergraduates in Barbados. World Academy of Science, Engineering and Technology International Journal of Educational and Pedagogical Sciences, 7(7), 2034-2038. doi: 10.5901/jesr.2012.v2n9p79.

Ferdinand, A. (2006). Metode penelitian manajemen. Edisi Kedua, Semarang: Universitas Diponegoro.

Fook, C. Y., Dalim, S. F., Narasuman, S., Sidhu, G. K., Fong, L. L., \& Keang, K. M. (2015). Relationship between active learning and self efficacy among students in higher education. International Academic Research Journal of Social Science, 1(2), 139148.

Freeman, S., Eddy, S. L., McDonough, M., Smith, M. K., Okoroafor, N. Jordt, H., \& Wenderoth, M. P. (2014). Active learning increases student performance in science, engineering, and mathematics. PNAS, 111(23), 84108415. https://doi.org/10.1073/pnas.1319030111.

Ghozali, I. (2013). Aplikasi Analisis Multivariate dengan Program IBM SPSS 21 Update PLS Regresi. Semarang: Badan Penerbit Universitas Diponegoro

Hilaliyah, H. (2015). Pengaruh Persepsi Mahasiswa Atas Bahasa Indonesia Dan Minat Belajar Terhadap Prestasi Belajar Bahasa Indonesia. Faktor Jurnal Ilmiah Kependidikan, II(2).

Jeong, J. S., Gómez-Gonzalez, D., Cañada-Cañada, F., Gallego-Pico, A., \& Bravo, J. C. (2019). Effects of active learning methodologies on the students' emotions, self-efficacy beliefs and learning outcomes in a science distance learning course. Journal of Technology and Science Education, 9(2), 217-227. https://doi.org/10.3926/jotse.530.

Mueller, A. L., Knobloch, N. A., \& Orvis, K. S. (2015). exploring the effects of active learning on high school students' outcomes and teachers' perceptions of biotechnology and genetics instruction. Journal of Agricultural Education, 56(2), 138-152. doi: 10.5032/jae.2015.02138.

Noreen, S., Hasan, A., Batool, I., \& Ali, A. (2018). The Impacts of Academic SelfEfficacy on Academic Outcomes: The Mediating effect of Student Engagement. International Journal of Academic Research in Business and Social Sciences, 8(11), 315-327. doi: 10.6007/IJARBSS/v8-i11/4904. 
Pajares, F. (1996). Self-efficacy beliefs in academic settings. Review of Educational Research Winter, 66(4), 543-578.

Papasraton, B., \& Wangpipatwong, T. (2006). The effect of self- efficacy attitude on eleaning outcomes. Proceeding of Word Conference on E-Learning in Corporate, Government, Healthcare, and Higher Education, Chesapeake, VA: AACE.

Putwain, D., Sander, P., \& Larkin, D. (2013). Academic self-efficacy in study-related skills and behaviours: Relations with learning-related emotions and academic success. British Journal of Educational Psychology, 83(4), 633-650. doi: 10.1111/j.20448279.2012.02084.x.

Rayung. M. N., \& Ambotang, S. A. (2018). The influence of emotional and spiritual intelligence on the high school student outcomes. Journal of Education \& Social Policy, 5(1), 211-220.

Salovey, P., Mayer, I. D., \& Caruso, D. R. (2002). The positive psychology of emotional intelligence. In C. R. Snyder, \& S. J. Lopez (Eds.), The handbook of positive psychology (pp. 159-171). New York: Oxford University Press.

Silberman, M. (2011). Active learning 101 strategies to teach any subject. Toronto: Alyn Bacon.

Sungur, S., \& Tekkaya, C. (2006). Effect of problem based learning and traditional instruction on self regulated learning. The Journal of Education Research, 9(9), 307317.

Zimmerman, B. J., \& Risemberg, R. (1997). Self-regulatory dimensions of academic learning and motivation. In G. D. Phye (Ed.), Handbook of academic learning: construction of knowledge. San Diego, CA: Academic Press. 